\title{
Proteoglycan 4, a Novel Immunomodulatory Factor, Regulates Parathyroid Hormone Actions on Hematopoietic Cells
}

\author{
Chad M. Novince, ${ }^{*}$ Amy J. Koh, ${ }^{*}$ \\ Megan N. Michalski, ${ }^{*}$ Julie T. Marchesan, ${ }^{*}$ \\ Jason Wang, ${ }^{*}$ Younghun Jung, ${ }^{*}$ Janice E. Berry, ${ }^{*}$ \\ Matthew R. Eber, ${ }^{*}$ Thomas J. Rosol, ${ }^{\dagger}$ \\ Russell S. Taichman, ${ }^{*}$ and Laurie K. McCauley* \\ From the Department of Periodontics and Oral Medicine,* School \\ of Dentistry, and the Department of Patbology, ${ }^{\ddagger}$ Medical School, \\ University of Michigan, Ann Arbor, Michigan; and the \\ Department of Veterinary Biosciences, ${ }^{\dagger}$ College of Veterinary \\ Medicine, The Obio State University, Columbus, Obio
}

Proteoglycan 4 (PRG4), a critical protective factor in articular joints, is implicated in hematopoietic progenitor cell expansion and megakaryopoiesis. PRG4 loss-of-function mutations result in camptodactyly-arthropathy-coxa varapericarditis (CACP) syndrome, which is characterized primarily by precocious joint failure. PRG4 was identified as a novel parathyroid hormone (PTH) responsiveness gene in osteoblastic cells in bone, and was investigated as a potential mediator of PTH actions on hematopoiesis. Sixteen-week-old Prg $4^{-/-}$mutant and $\operatorname{Prg} 4^{+/+}$wild-type mice were treated daily with intermittent PTH (residues 1-34) or vehicle for 6 weeks. At 22 weeks of age, Prg 4 mutant mice had increased peripheral blood neutrophils and decreased marrow $\mathrm{B220}^{+}$(B-lymphocytic) cells, which were normalized by PTH. The PTH-induced increase in marrow $\mathrm{Lin}^{-} \mathrm{Sca}-1^{+} \mathrm{c}-\mathrm{Kit}^{+}$(hematopoietic progenitor) cells was blunted in mutant mice. Basal and PTHstimulated stromal cell-derived factor-1 (SDF-1) was decreased in mutant mice, suggesting SDF- 1 as a candidate regulator of proteoglycan 4 actions on hematopoiesis $i n$ vivo. PTH stimulation of IL-6 mRNA was greater in mutant than in wild-type calvaria and bone marrow, suggesting a compensatory mechanism in the PTH-induced increase in marrow hematopoietic progenitor cells. In summary, proteoglycan 4 is a novel PTH-responsive factor regulating immune cells and PTH actions on marrow hematopoietic progenitor cells. (Am J Pathol 2011, 179:2431-2442; DOI: 10.1016/j.ajpath.2011.07.032)
Parathyroid hormone (PTH), best known for its roles in calcium homeostasis and bone remodeling, ${ }^{1}$ supports hematopoietic progenitor cell (HPC) expansion and mobilization. $^{2-4}$ Although clinical investigations are assessing intermittent PTH administration as a potential stem cell therapy after bone marrow transplants, ${ }^{5}$ the mechanisms mediating PTH actions on hematopoiesis are poorly understood.

Stromal osteoblastic cells are the dominant cell type expressing PTH/PTH-related protein (PTHrP) receptor (PPR) in the bone marrow. With the exception of specific PPRexpressing T-cell subpopulations, ${ }^{6,7}$ PTH actions on hematopoiesis are thought to be mediated via paracrine or juxtacrine signaling from PPR-activated stromal osteoblastic cells. ${ }^{1,2,8}$

PPR signaling in stromal osteoblastic cells alters the expression of osteoclastic cytokines, most notably receptor activator of nuclear factor- $\kappa \mathrm{B}$ ligand (RANKL) and osteoprotegerin (OPG), which regulate the differentiation of hematopoietic cells to mature bone resorbing osteoclastic cells. ${ }^{8-12}$ More recent studies have focused on the role of PTH actions on HPCs. Calvi et $\mathrm{al}^{2}$ demonstrated in mutant mice with osteoblast-specific constitutively active PPR that osteoblastic cells increase HPC expansion via Jagged1 ligand. Further investigation revealed that intermittent PTH administration in normal mice supported hematopoiesis through actions on early HPCs. $^{2}$ Ex vivo and in vivo PTH studies by Pirih et $\mathrm{al}^{13}$ using the global IL-6 knockout mouse model demonstrated that IL-6 supports PTH expansion of HPCs.

The proteoglycan 4 gene (human PRG4; murine Prg4), which has been implicated in HPC expansion ${ }^{14-16}$ and megakaryopoiesis, ${ }^{17-19}$ was identified as a novel PTH-

Supported by NIH grants DE019395 (L.K.M.), DK53904 (L.K.M.), DE007057 (University of Michigan-T32), and DE021298 (C.M.N.-F30).

Accepted for publication July 7, 2011.

Supplemental material for this article can be found at http://ajp. amjpathol.org or at doi: 10.1016/j.ajpath.2011.07.032.

Address reprint requests to Laurie K. McCauley, D.D.S., Ph.D., Professor and Chair; Department of Periodontics and Oral Medicine, School of Dentistry, University of Michigan, 1011 N. University Ave., Ann Arbor, MI 48109. E-mail: mccauley@umich.edu. 
Table 1. PRG4 Protein Products

\begin{tabular}{|c|c|c|c|}
\hline Protein product & Isolation & Expression & Known functions \\
\hline Lubricin $^{23}$ & Bovine synovial fluids & Synoviocytes & $\begin{array}{l}\text { Boundary lubrication of synovial } \\
\text { joints }\end{array}$ \\
\hline $\begin{array}{l}\text { Superficial zone protein } \\
(\text { SZP })^{24}\end{array}$ & $\begin{array}{l}\text { Bovine superficial zone articular } \\
\text { cartilage explant culture media }\end{array}$ & $\begin{array}{l}\text { Superficial zone articular } \\
\text { chondrocytes }\end{array}$ & $\begin{array}{l}\text { Protects superficial zone articular } \\
\text { cartilage }\end{array}$ \\
\hline Hemangiopoietin (HAPO) ${ }^{14}$ & $\begin{array}{l}\text { Urine of patients afflicted by } \\
\text { aplastic anemia }\end{array}$ & Unknown & $\begin{array}{l}\text { Supports hematopoietic and } \\
\text { endothelial progenitor cells }\end{array}$ \\
\hline $\begin{array}{l}\text { Megakaryocyte stimulating } \\
\text { factor (MSF) }\end{array}$ & $\begin{array}{l}\text { Urine of bone marrow transfer } \\
\text { patients afflicted by acute } \\
\text { thrombocytopenia }\end{array}$ & Unknown & Regulates megakaryopoiesis \\
\hline
\end{tabular}

responsive gene in bone. ${ }^{20,21}$ The PRG4 gene encodes an approximately $345-\mathrm{kDa}$ proteoglycan, consisting of 1404 amino acids spanning 12 exons. PRG4 is expressed across skeletal and nonskeletal tissues, with highest relative levels of expression in articular joints, liver, and bone. ${ }^{22,23}$ The four isolated PRG4 protein products [ie, lubricin, superficial zone protein (SZP), hemangiopoietin (HAPO), and megakaryocyte stimulating factor (MSF)] are secreted glycoproteins that have been implicated in articular joint protection, ${ }^{23,24}$ HPC expansion, ${ }^{14}$ and megakaryopoiesis ${ }^{17}$ (Table 1). A proteoglycan 4 receptor has not yet been identified. ${ }^{14,23}$ Loss-of-function mutations in PRG4 result in the human autosomal recessive disorder known as camptodactyly-arthropathy-coxa vara-pericarditis syndrome (CACP), which is characterized by early-onset joint failure and osteopenia. CACP patients have not been reported to spontaneously develop hematological disorders. ${ }^{25}$

Although selected studies have reported that HAPO supports HPC expansion ${ }^{14-16}$ and that MSF regulates megakaryopoiesis, ${ }^{17-19}$ the actions of proteoglycan 4 on hematopoiesis are unclear. The purpose of the present study was to investigate the unexplored role of proteoglycan 4 as a regulator of physiological hematopoiesis and PTH actions on hematopoiesis in the mature skeleton. Using the Prg4-null mouse model, ${ }^{23}$ we report the first known study of Prg4 actions on hematopoiesis in vivo.

\section{Materials and Methods}

\section{C57BL/6 Wild-Type Mice, Single PTH Administration}

Sixteen-week-old C57BL/6 wild-type mice were administered a single subcutaneous injection of recombinant human $\mathrm{PTH}$ residues 1 to 34 [PTH(1-34); $1 \mu \mathrm{g} / \mathrm{g}$ ] (Bachem, Torrance, CA) or vehicle $(0.9 \% \mathrm{NaCl})$ and then were sacrificed 4,8 , or 12 hours later; bone marrow was harvested for gene expression analysis. All animal studies were approved by the University Committee on the Use and Care of Animals (UCUCA) of the University of Michigan, and animals were maintained in accordance with approved UCUCA research protocols.

\section{Primary Calvarial Osteoblastic Cell Cultures, Single PTH Administration}

Primary osteoblasts were isolated from calvariae harvested from 7- to 14-day-old C57BL/6 wild-type mice.
Briefly, calvariae were dissected, isolated from periosteum, and subjected to sequential digestion for 10, 20, and 60 minutes in $\alpha$-modified minimum essential medium (Invitrogen, Carlsbad, CA) containing collagenase A (2 $\mathrm{mg} / \mathrm{mL}$ ) (Roche Molecular Biochemicals, Indianapolis, IN) and $0.25 \%$ trypsin (Invitrogen). Cells from the last digest were washed, counted, and plated at $5 \times 10^{4} / \mathrm{cm}^{2}$ in $\alpha$-modified minimum essential medium with $10 \%$ fetal bovine serum (Invitrogen), $100 \mathrm{U} / \mathrm{mL}$ penicillin, $100 \mathrm{mg} / \mathrm{mL}$ streptomycin, and $2 \mathrm{mmol} / \mathrm{L}$ glutamine. Cells were induced to differentiate by supplementing medium with $50 \mu \mathrm{g} / \mathrm{mL}$ ascorbic acid.

Cultures at day 5 (d5) were administered a single recombinant human $\mathrm{PTH}(1-34)(10 \mathrm{nmol} / \mathrm{L})$ (Bachem) or vehicle ( $4 \mathrm{mmol} / \mathrm{L} \mathrm{HCl} / 0.1 \% \mathrm{BSA})$ treatment and were harvested 8,12 , or 24 hours later for gene expression analysis. In another experimental protocol, d1, d5, d11, and d14 cultures were administered a single recombinant human $\mathrm{PTH}(1-34)$ (10 nmol/L) (Bachem) or vehicle (4 $\mathrm{mmol} / \mathrm{L} \mathrm{HCl} / 0.1 \% \mathrm{BSA}$ ) treatment and were harvested 4 hours later for gene expression analysis.

\section{Background of Prg4 ${ }^{-1-}$ Mutant Mice}

Prg $^{-1-}$ mutant mice with a mutant Prg4 allele generated by homologous recombination in 129Sv/Ev-derived embryonic stem cells were generously provided by Matthew Warman (Harvard University). ${ }^{23}$ Mutant mice were backcrossed from the 129Sv/Ev genetic background to the C57BL/6 genetic background. A PCR-based assay was used to genotype the mice, as described previously. ${ }^{23}$

\section{Prg4 $^{-1-}$ Mutant Mice, Single PTH Administration}

At 16 weeks of age, Prg4 ${ }^{-1-}$ mutant and Prg $4^{+/+}$wildtype littermate mice were administered a single subcutaneous injection of recombinant human $\mathrm{PTH}(1-34)$ (1 $\mu \mathrm{g} / \mathrm{g})$ (Bachem) or vehicle $(0.9 \% \mathrm{NaCl})$ and then were sacrificed 1, 4, 8, or 12 hours later; bone marrow and calvariae were harvested for gene expression analysis.

\section{Prg4 ${ }^{-1-}$ Mutant Mice, 6 Weeks Daily Intermittent PTH Administration}

In an intermittent PTH experimental protocol, 16-week-old $\mathrm{Prg}^{-1-}$ mutant and Prg $4^{+/+}$wild-type littermate mice were administered intermittent daily subcutaneous injection of recombinant human $\mathrm{PTH}(1-34) \quad(50 \mu \mathrm{g} / \mathrm{kg})$ 
(Bachem) or vehicle $(0.9 \% \mathrm{NaCl})$ control for 6 weeks, to 22 weeks of age. Mice were sacrificed 24 hours after the final injection, and tissues were harvested for analyses.

\section{Quantitative Real-Time PCR}

Bone marrow was directly flushed from femur and tibia with TRIzol reagent (Invitrogen) using a 3-mL syringe and $22 \mathrm{G} 1 / 2$-inch ( $12.7-\mathrm{mm}$ length) needle. Calvariae were flash-frozen, pulverized, and homogenized in TRIzol reagent. Calvarial osteoblast cultures were washed three times with $1 \times$ PBS, and TRIzol was directly applied to cultures. In each case, RNA was isolated according to manufacturer's directions, and total RNA was quantified. Double-stranded cDNA was synthesized from $1.0 \mu \mathrm{g}$ of RNA, using random hexamers and MultiScribe reverse transcriptase (Applied Biosystems, Foster City, CA). cDNA was amplified using the TaqMan universal PCR master mix with TaqMan gene expression-specific primers and probes (Applied Biosystems) for proteoglycan 4 (PRG4), interleukin-6 (IL-6), thrombopoietin (TPO), stromal cell-derived factor-1 (SDF-1), and osteocalcin (OCN). Rodent glyceraldehyde-3-phosphate dehydrogenase (GAPDH) (Applied Biosystems) was used as an endogenous control. Amplification was performed using the ABI Prism 7700 sequence detection system (Applied Biosystems). Relative quantification of data were determined using the standard curve method or the comparative $C_{t}$ method. ${ }^{26}$

\section{Complete Blood Counts}

Whole blood was collected by cardiac puncture, transferred to Microtainer tubes with potassium-EDTA (BD Biosciences, San Jose, CA) and gently agitated. Complete blood count analysis (automated differential) was performed using a Hemavet 1500FS system (Drew Scientific, Waterbury, CT).

\section{Flow Cytometry}

Flushed femoral bone marrow cells and dissociated spleen cells were isolated, and all staining steps were performed using flow cytometry staining buffer (FCSB) (1× PBS, $2 \%$ fetal bovine serum, $2 \mathrm{mmol} / \mathrm{L}$ EDTA). Femurs were sectioned at the mid-diaphysis, a 22G $1 / 2$-inch needle was gently rotated through the epiphysis into the marrow cavity, and marrow cells were flushed out from the sectioned mid-diaphysis with FCSB. Spleens were incised lengthwise, placed on a cell strainer, and disassociated with a 1-mL syringe plunger while FCSB was being delivered at the same time. Cell suspensions were homogenized, strained, centrifuged, and resuspended; cell counts were then performed. Three million cells were suspended in $0.5 \mathrm{~mL}$ FCSB, incubated with fluorochrome-conjugated antibodies (BD Biosciences) for 30 minutes at $4^{\circ} \mathrm{C}$, and then were washed, centrifuged, and resuspended in $1 \mathrm{~mL}$ FCSB containing 7-AAD (Invitrogen) for analysis. All antibodies were from BD Biosciences. The frequency of $\mathrm{CD} 11 \mathrm{~b}^{+} \mathrm{GR} 1^{+}$(immature myeloid) cells, $\mathrm{CD}^{+}$(T-lymphocytic) cells, B220 ${ }^{+}$
(B-lymphocytic) cells, $\mathrm{Lin}{ }^{-} \mathrm{Sca}-1^{+} \mathrm{C}-\mathrm{Kit}^{+}$(hematopoietic progenitor) cells, and $\mathrm{CD} 41^{+}$(megakaryopoietic) cells were assessed in bone marrow. The frequency of $\mathrm{B}_{220^{+}}$ cells was assessed in spleens. Samples were analyzed using a FACSCalibur flow cytometer and CellQuest Pro software version 5.1 (BD Biosciences).

A flow cytometry double-staining technique was used to assess megakaryocyte ploidy. Three million femoral bone marrow cells were suspended in $0.5 \mathrm{~mL}$ FCSB, incubated with FITC-conjugated CD41 antibody for 30 minutes at $4^{\circ} \mathrm{C}$, rinsed with $1 \times$ PBS, centrifuged, and fixed in $1 \mathrm{~mL} 1 \%$ paraformaldehyde overnight at $4^{\circ} \mathrm{C}$. Cells were centrifuged, washed with $1 \times$ PBS, resuspended in $1 \mathrm{~mL}$ propidium iodide staining solution ( $1 \times$ PBS, $4 \mathrm{mmol} / \mathrm{L}$ sodium citrate, $0.1 \%$ Triton $X-100,50$ $\mu \mathrm{g} / \mathrm{mL}$ propidium iodide, and $100 \mu \mathrm{g} / \mathrm{mL}$ RNase A), and incubated for 1 hour at $37^{\circ} \mathrm{C}$. A minimum of 10,000 gated cells were analyzed for each sample. Samples were analyzed using a FACSCalibur flow cytometer and CellQuest Pro software version 5.1 (BD Biosciences).

\section{Histomorphometry}

Tibiae were fixed in $10 \%$ phosphate-buffered formalin for 48 hours at $4{ }^{\circ} \mathrm{C}$, dehydrated in graded ethanols and xylene, and embedded in modified methylmethacrylate. Frontal serial sections $(4 \mu \mathrm{m})$ were cut with vertical bed microtomes (Jung 2065 and 2165; Leica Microsystems, Bannockburn, IL) and affixed to slides precoated with $1 \%$ gelatin solution. Sections were stained according to the von Kossa method with a tetrachrome counterstain (Polysciences, Warrington, PA), and used to enumerate megakaryocytes per marrow area. Histomorphometric data were collected semiautomatically with a Nikon light microscope and the OsteoMeasure trabecular analysis system (OsteoMetrics, Atlanta, GA).

Tibiae, liver (left lobe), and spleen were fixed in 10\% phosphate-buffered formalin for 48 hours at $4^{\circ} \mathrm{C}$. Tibiae were decalcified in $14 \%$ EDTA for 14 days at room temperature. Tibiae, liver, and spleen were embedded in paraffin, and $5-\mu \mathrm{m}$-thick serial sections were cut and stained. H\&E staining was performed on all tissue sections.

SDF-1 immunofluorescence analysis was performed in proximal tibia sections. Samples were deparaffinized with mixed xylenes, rehydrated in graded ethanols, and then briefly washed with PBT (PBS-0.2\% Triton X-100) and blocked for 30 minutes with Image-iT FX signal enhancer (Invitrogen). SDF-1 immunofluorescence analysis was performed using a Zenon AlexaFluor 488 rabbit labeling kit (Invitrogen) and SDF-1 $\alpha$ rabbit polyclonal antibody (ab25117; Abcam, Cambridge, MA). After overnight incubation at $4^{\circ} \mathrm{C}$ with $1 \mu \mathrm{g} / 100 \mu \mathrm{L}$ dilution of fluorescencelabeled SDF-1 $\alpha$ rabbit polyclonal antibody (Abcam), sections were washed with PBT, mounted with ProLong Gold antifade reagent with DAPI (Invitrogen), and coverslipped. Images were acquired with an Olympus FV-500 confocal microscope. Image analysis of SDF-1 immunofluorescence in proximal tibia trabecular bone (secondary spongiosa) was performed using Image Pro Plus version 5.1 software (Media Cybernetics, Silver Spring, MD). 


\section{Bone Marrow Biochemical Studies}

Bone marrow was directly flushed from femur and tibia with $1 \mathrm{~mL} 0.9 \% \mathrm{NaCl}$ using a $1-\mathrm{mL}$ syringe and a $22 \mathrm{G}$ $1 / 2$-inch needle. The marrow suspension was homogenized and cell counts performed. Cell suspensions were centrifuged at $81.6 \times g$ for 5 minutes, supernatants were collected, stored at $-80^{\circ} \mathrm{C}$, and freeze-thawed once. SDF-1 levels in the bone marrow supernatant were analyzed by antibody sandwich enzyme-linked immunosorbent assay (R\&D Systems, Minneapolis, MN) according to the manufacturer's protocol, with a detection range of 62.5 to $10,000 \mathrm{pg} / \mathrm{mL}$. SDF-1 levels were normalized to marrow cell numbers.

\section{Statistical Analysis}

Analysis of variance and unpaired $t$-test were performed using GraphPad Instat software version 3.10 (GraphPad Software, San Diego, CA). Statistical significance was set at $P \leq 0.05$. Data are expressed as means \pm SEM.

\section{Results}

\section{Single PTH Administration Increases Prg4 mRNA Levels in Bone}

Quantitative real-time PCR studies demonstrated that Prg4 is a novel PTH-responsiveness gene in bone, both in vivo and in vitro (Figure $1, \mathrm{~A}-\mathrm{C})$. A single subcutaneous injection of PTH(1-34) $(1 \mu \mathrm{g} / \mathrm{g})$ in 16-week-old C57BL/6 wild-type mice significantly increased Prg4 mRNA in bone marrow at 4 and 8 hours after injection (Figure 1A). Moreover, a single PTH(1-34) administration (10 nmol/L) to primary calvarial osteoblastic cell cultures significantly up-regulated Prg4 mRNA at 8, 12, and 24 hours after treatment (Figure 1B).
Prg4 mRNA expression was evaluated in d1, d5, d11, and $\mathrm{d} 14$ primary calvarial osteoblastic cell cultures to elucidate the role of osteoblast maturation on basal and PTH-stimulated Prg4 mRNA expression. Basal Prg4 mRNA expression was highest in less differentiated osteoblastic cell cultures and significantly decreased with increasing differentiation over time (Figure 1C). At 4 hours, a single PTH administration significantly increased Prg4 mRNA at all stages of differentiation. Relative to vehicle-control samples, PTH significantly increased Prg4 mRNA at day 1 (1.5-fold), day 5 (2.8-fold), day 11 (5.3-fold), and day 14 (24.4-fold) (Figure 1C). Osteocalcin gene expression studies validated the maturation of osteoblastic cells in culture over time (Figure 1D), as we have previously reported. ${ }^{27}$

\section{Bone Marrow, Liver, and Spleen Morphology}

Tibia, liver, and spleen were isolated after 6 weeks of PTH or vehicle treatment (ie, 22-week-old mice) for histological evaluation of hematopoietic organs (Figure 2, A-C). Proximal tibia marrow morphology was similar in 22week-old Prg4 ${ }^{-1-}$ and Prg4 ${ }^{+/+}$mice (Figure 2A). Likewise, there were no morphological differences found in 22-week-old Prg4 ${ }^{-1-}$ liver (Figure 2B) or spleen (Figure 2C) relative to $P r g 4^{+/+}$littermates, and no evidence of extramedullary hematopoiesis in these organs.

\section{Bone Marrow IL-6, Thrombopoietin, and SDF-1 $m R N A$ in $\mathrm{Prg}^{-/-}$Mice}

Based on previous reports implicating the Prg4 protein products HAPO and MSF in HPC expansion ${ }^{14-16}$ and megakaryopoiesis, ${ }^{17-19}$ we evaluated the expression of several genes that are dual regulators of HPCs and megakaryopoiesis. Sixteen-week-old $\mathrm{Prg}^{-1-}$ and $\mathrm{Prg}^{+/+}$mice were administered a single subcutaneous
A

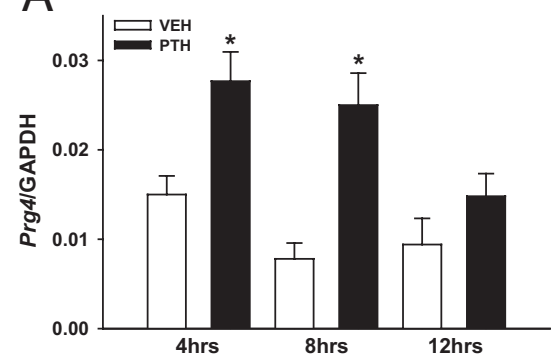

C

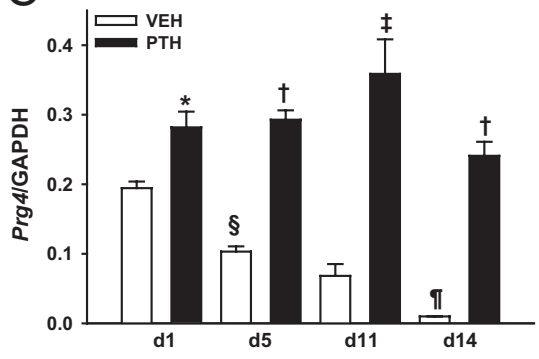

B

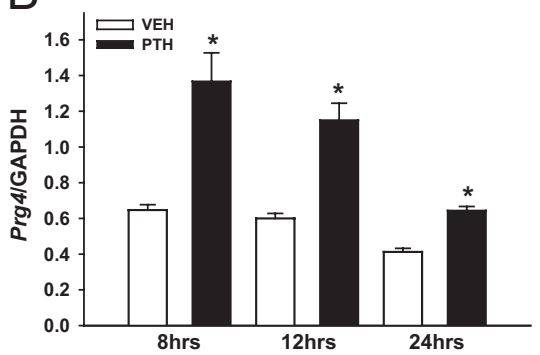

D

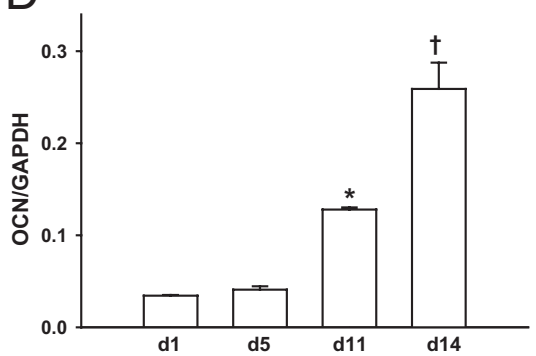

Figure 1. PTH regulation of $\operatorname{Prg} 4$ mRNA. A: Sixteenweek-old C57BL/ 6 wild-type mice were administered a single subcutaneous injection of PTH(1-34) $(1 \mu \mathrm{g} / \mathrm{g})$ or vehicle $(\mathrm{VEH})(0.9 \% \mathrm{NaCl})$ control and then were sacrificed 4,8 , or 12 hours later; bone marrow was harvested for $\operatorname{Prg} 4$ mRNA expression analysis ( $n=5$ per group). ${ }^{*} P<0.05$ versus VEH. B: C57BL/ 6 wild-type mouse-derived calvarial osteoblast cultures were administered a single treatment of PTH $(10 \mathrm{nmol} / \mathrm{L})$ or vehicle (VEH) ( $4 \mathrm{mmol} / \mathrm{L} \mathrm{HCl} / 0.1 \% \mathrm{SA})$ and were harvested 8,12 , or 24 hours later for Prg 4 mRNA expression analysis ( $n=7$ per group). ${ }^{*} P<0.01$ versus VEH C: C57BL/6 wild-type mouse-derived calvarial osteoblast cultures, $1,5,11$, and 14 days after plating, were administered a single treatment of PTH $(10 \mathrm{nmol} / \mathrm{L})$ or vehicle $(\mathrm{VEH})(4 \mathrm{mmol} / \mathrm{L} \mathrm{HCl} / 0.1 \% \mathrm{BSA})$ treatment and were harvested 4 hours later for Prg 4 mRNA expression analysis ( $n=3$ per group). ${ }^{*} P<0.05$, PTH versus $\mathrm{VEH} ;{ }^{\dagger} P<0.001$, PTH versus VEH; ${ }^{\ddagger} P<0.01$, PTH versus VEH; ${ }^{\circledR} P<0.01, \mathrm{~d} 5$-VEH versus d1-VEH; ${ }^{\top \pi} P<$ 0.05 , d14-VEH versus d11-VEH. D: From the same cultures as in $\mathbf{C}$, osteocalcin (OCN) mRNA expression was assessed as a marker of osteoblast differentiation. ${ }^{*} P<0.001, \mathrm{~d} 11$ versus $\mathrm{d} 5 ;{ }^{\dagger} P<0.05, \mathrm{~d} 14$ versus d11. RNA was isolated and quantitative real-time PCR was performed to assess Prg $4 \mathrm{mRNA}$ and OCN mRNA expression (standardized to GAPDH levels). Relative quantification of data generated was determined using the standard curve method. Data are expressed as means \pm SEM. 
A

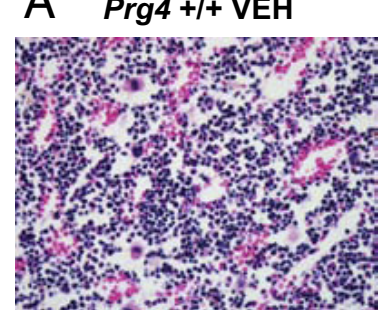

Prg4 +/+ PTH

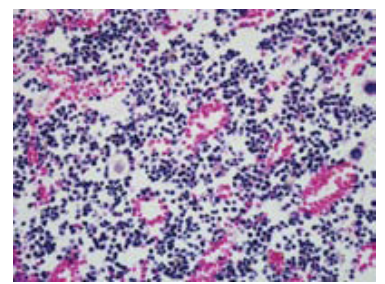

\section{B Prg4 +/+ VEH}

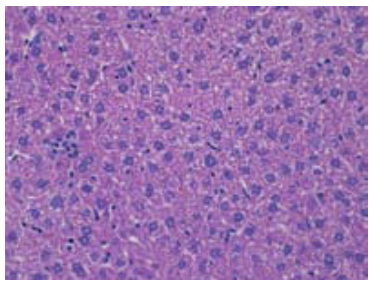

Prg4 +/+ PTH

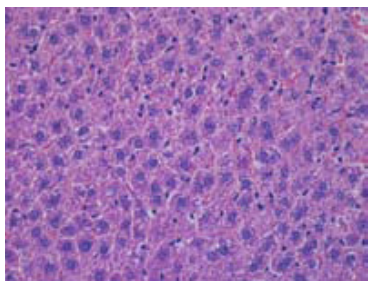

C Prg $4+/+$ VEH

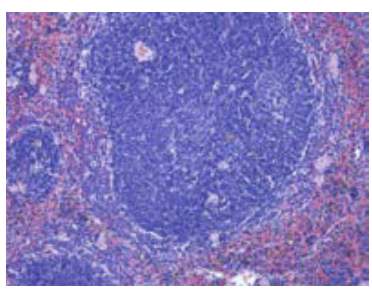

Prg4 +/+ PTH

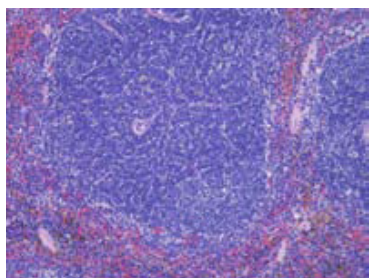

Prg 4 -/- VEH

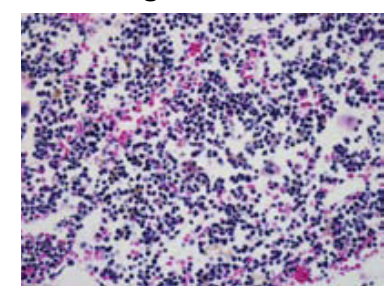

Prg 4 -/- PTH

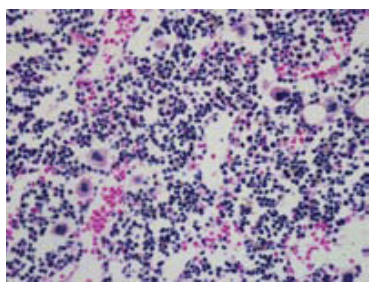

Prg 4 -/- VEH

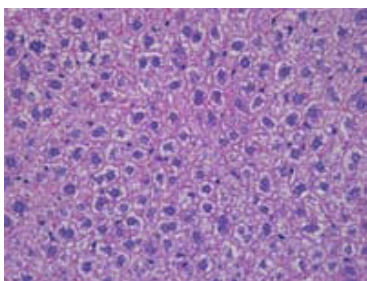

Prg4 -/- PTH

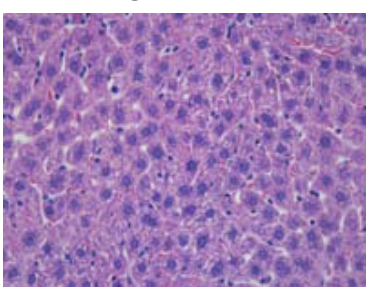

Prg 4 -/- VEH

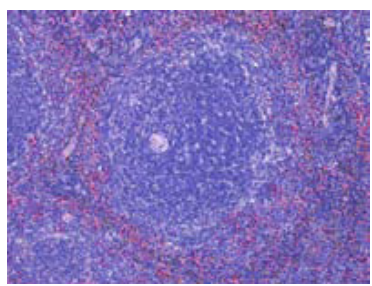

Prg4 -/- PTH

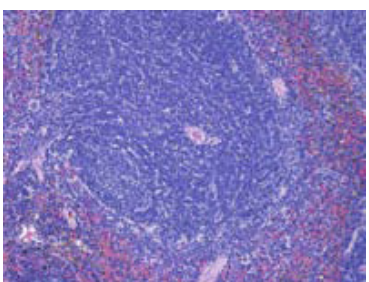

Figure 2. Histological assessment of bone marrow, liver, and spleen. $\operatorname{Prg} 4^{-/-}$mutant and $\operatorname{Prg} 4^{+/+}$wild-type mice were administered intermittent PTH(1-34) $(50 \mu \mathrm{g} / \mathrm{kg})$ or vehicle (VEH) $(0.9 \% \mathrm{NaCl})$ control subcutaneous injections daily for 6 weeks, from age 16 weeks to 22 weeks. Tibia, liver, and spleen were isolated from 22-week-old $\operatorname{Prg} 4^{-1-}$ and $\operatorname{Prg} 4^{+/+}$mice for histological evaluation. Images are representative images of H\&E-stained proximal tibia bone marrow sections ( $n \geq 10$ per group) (A), liver section ( $n \geq 5$ per group) (B), and spleen sections ( $n \geq 5$ per group) (C). Original magnification: $\times 40(\mathbf{A}$ and $\mathbf{B}) ; \times 20(\mathbf{C})$ injection of PTH(1-34) $(1 \mu \mathrm{g} / \mathrm{g})$ or vehicle $(0.9 \% \mathrm{NaCl})$ control and then were sacrificed 1, 4, 8, or 12 hours later; bone marrow total RNA was isolated, and quantitative real-time PCR was performed to assess IL-6, TPO, and SDF-1 mRNA expression.

IL-6 is a pleiotropic factor with diverse biological roles, including the support of hematopoiesis, lymphopoiesis, $^{28,29}$ and megakaryopoiesis. ${ }^{30,31}$ Marrow IL-6 mRNA levels were significantly lower in control 16-week-old $\mathrm{Prg}^{-1-}$ mice and were consistently expressed at $60 \%$ of the levels detected in Prg $4^{+/+}$littermates (Figure 3A). $I L-6$ is an immediate early-response gene up-regulated in bone in vitro and in vivo by PTH at 30 minutes to 1 hour after administration. ${ }^{32-34}$ IL-6 mRNA levels were significantly increased at 1 hour after PTH injection in 16-weekold Prg $4^{-1-}$ and $P r g 4^{+/+}$marrow, returning to baseline at 4 hours. Relative to vehicle-control samples, PTH injection increased IL-6 mRNA to a significantly greater extent at 1 hour in $\mathrm{Prg}^{-1-}$ marrow (13-fold) than in $\mathrm{Prg}^{+/+}$ marrow (fivefold) $(P<0.01)$ (Figure 3A).

IL6 gene expression studies were performed in calvariae harvested from untreated and single PTH-treated 16-week-old Prg4 ${ }^{-1-}$ and Prg4 ${ }^{+/+}$mice to characterize the cellular target mediating the exacerbated PTH-induced increase in marrow IL-6 mRNA in Prg4 ${ }^{-1-}$ mice. Relative to controls, $\mathrm{PTH}$ injection induced a significantly greater increase in calvarial IL-6 mRNA in $\mathrm{Prg}^{-1-}$ (132-fold) than in $\mathrm{Prg}^{+/+}$mice (45-fold) at 1 hour after treatment $(P<0.05)$, substantiating an osteoblast target (Figure $3 \mathrm{~B}$ ).

TPO, the primary factor regulating megakaryopoiesis, has been shown to support HPCs. ${ }^{35}$ Marrow TPO mRNA expression was similar in control 16-week-old Prg4 ${ }^{-1-}$ and $\mathrm{Prg}^{+/+}$mice, and PTH did not alter marrow TPO mRNA levels in $\mathrm{Prg}^{-/-}$or Prg $4^{+/+}$mice (Figure $3 \mathrm{C}$ ).

SDF-1, a chemokine expressed at high levels by bone marrow stromal osteoblastic cells, regulates the homing and mobilization of marrow HPCs, ${ }^{36,37}$ megakaryocyte progenitor cells, ${ }^{38}$ and immune cell populations. ${ }^{39,40} \mathrm{Al}-$ though intermittent PTH treatment has been reported to increase SDF-1 mRNA expression in bone, in vitro and in vivo, ${ }^{41}$ little is known regarding the temporal effects of PTH on SDF-1 mRNA expression. At 4 hours after PTH injection, marrow SDF-1 mRNA levels were reduced similarly in 16-week-old $\mathrm{Prg}^{-1-}$ and $\mathrm{Prg}^{+/+}$mice. At 12 hours after PTH injection, marrow SDF-1 mRNA was significantly increased in $\mathrm{Prg}^{+/+}$mice but PTH notably failed to increase marrow SDF-1 mRNA in Prg4 ${ }^{-1-}$ mice (Figure 3D). Gene expression studies in calvariae harvested from untreated and single PTH-treated 16-weekold $\mathrm{Prg}^{-1-}$ and $\mathrm{Prg}^{+/+}$mice demonstrated no change in SDF-1 mRNA expression at 12 hours after treatment (data not shown).

\section{Prg4 ${ }^{-/-}$Mice Have Altered Immune Cell Populations, Normalized by PTH}

Whole blood was collected from 22-week-old PTHtreated and vehicle-treated $\mathrm{Prg}^{-1-}$ and $\mathrm{Prg}^{+/+}$mice, and complete blood count studies were performed to 
A
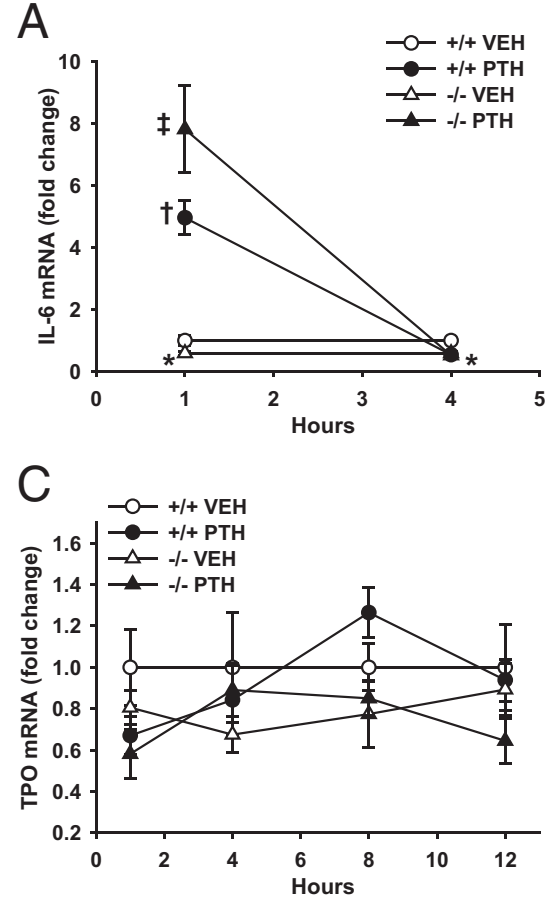

B

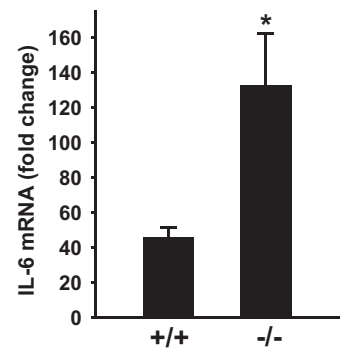

D

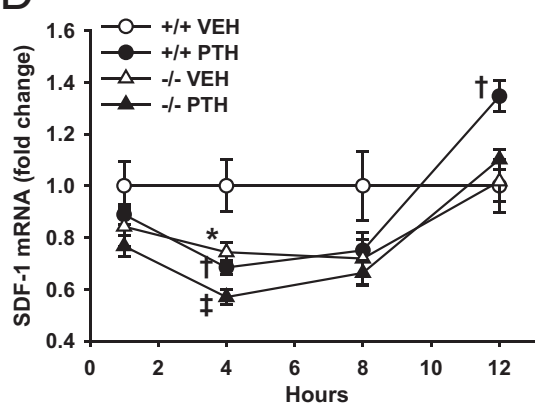

Figure 3. PTH regulation of gene expression. A, C, and D: Sixteen-week-old Prg $4^{-1-}$ mutant and $\operatorname{Prg} 4^{+/+}$wild-type mice were administered a single subcutaneous injection of PTH(1-34) $(1 \mu \mathrm{g} / \mathrm{g})$ or vehicle $(\mathrm{VEH})(0.9 \% \mathrm{NaCl})$ control and then were sacrificed $1,4,8$, or 12 hours later; bone marrow was harvested for gene expression analysis $(n=5$ per group). RNA was isolated and quantitative real-time PCR was performed to assess mRNA expression of IL-6 (A), TPO (C), and SDF-1 (D), standardized to GAPDH levels. Relative quantification of data was determined using the comparative $\mathrm{C}_{\mathrm{t}}$ method. B: Sixteen-week-old $\operatorname{Prg} 4^{-/-}$and $\operatorname{Prg} 4^{+/+}$mice were untreated or administered a single subcutaneous injection of PTH(1-34) (1 $\mu \mathrm{g} / \mathrm{g})$ and then were sacrificed 1 hour later; calvariae were harvested for gene expression analysis ( $n=5$ per group). RNA was isolated and quantitative real-time PCR was performed to assess IL-6 mRNA expression (standardized to GAPDH levels). Values are expressed as treatment over no treatment control within treatment groups. A: Marrow IL- 6 mRNA fold change at 1 and 4 hours after PTH injection. ${ }^{*} P<0.05,-/-$ VEH versus $+/+\mathrm{VEH} ;{ }^{\dagger} P<0.001,+/+$ PTH versus $+/+\mathrm{VEH} ;$ ${ }^{\ddagger} P<0.001,-/-$ PTH versus $-/-$ VEH. B: Calvarial IL-6 mRNA fold change at 1 hour after PTH injection. ${ }^{*} P<0.05,-/-$ PTH versus $+/+$ PTH. C: Marrow TPO mRNA fold change at $1,4,8$, and 12 hours after PTH injection. D: Marrow SDF-1 mRNA fold change at 14,8 , and 12 hours after PTH injection. ${ }^{*} P<0.05,-/-$ VEH versus $+/+\mathrm{VEH} ;{ }^{\dagger} P<0.05,+/+$ PTH versus $+/+$ VEH; ${ }^{\ddagger} P<0.01,-/-$ PTH versus $-/-$ VEH. Data are expressed as means \pm SEM assess peripheral blood cell populations. There were no differences in red blood cell values or platelet numbers between $\operatorname{Prg}^{-1-}$ and Prg $4^{+/+}$mice (see Supplemental Table S1 at http://ajp.amjpathol.org). Prg $4^{-1-}$ mice had altered peripheral white blood cells, including increased percentages of neutrophils and decreased percentages of lymphocytes (Figure 4, A and B; see also Supplemental Table S1 at http://ajp.amjpathol.org). Unexpectedly, PTH treatment normalized the frequency of peripheral blood neutrophils and lymphocytes in $\mathrm{Prg}^{-1-}$ mice to the levels of $\mathrm{Prg}^{+/+}$mice (Figure 4, A and B; see also Supplemental Table S1 at http://ajp.amjpathol.org). Analysis of absolute cell numbers revealed that $\operatorname{Prg}^{-1-}$ mice had increased numbers of neutrophils that were normalized by PTH (Figure 4, C and D; see also Supplemental Table S1 at http://ajp.amjpathol.org).

To elucidate whether differences in peripheral blood immune cells reflected changes in the marrow, femoral bone marrow was harvested from 22-week-old $\mathrm{Prg}^{-1-}$ and $\mathrm{Prg}^{+/+}$mice for flow cytometric analysis of
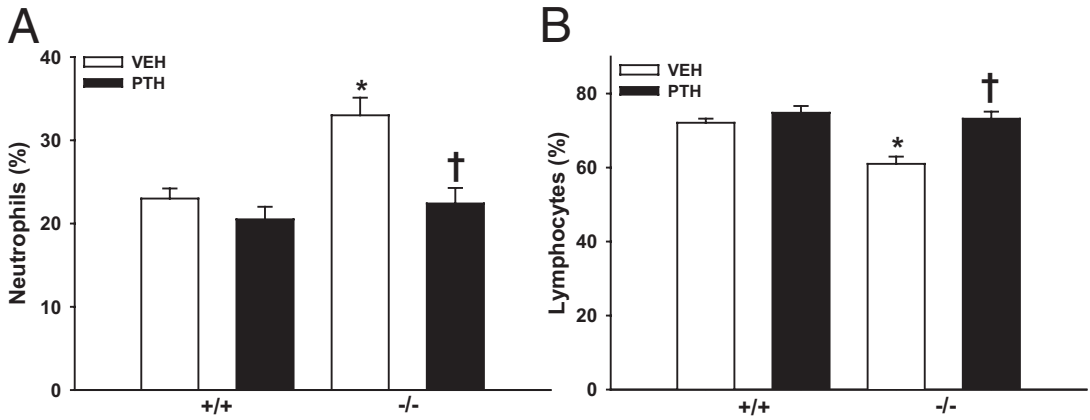

C
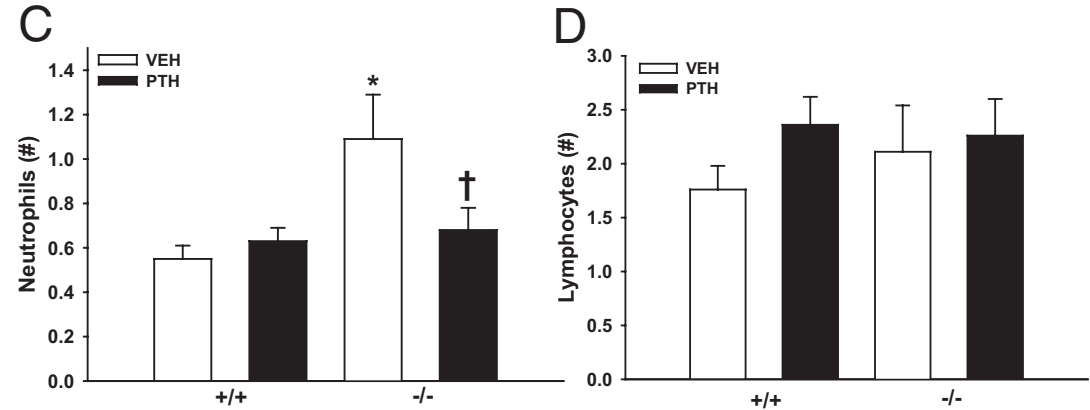

Figure 4. Peripheral blood cell analyses. A-D: $\mathrm{Prg}^{-/-}$mutant and Prg $4^{+/+}$wild-type mice were administered intermittent PTH(1-34) $(50 \mu \mathrm{g} / \mathrm{kg})$ or vehicle $(\mathrm{VEH})(0.9 \% \mathrm{NaCl})$ control subcutaneous injection daily for 6 weeks, from age 16 weeks to 22 weeks. Peripheral blood was isolated via cardiac puncture from 22-week-old $\mathrm{Prg}^{-1-}$ and $\mathrm{Prg} 4^{+/+}$ mice and complete blood count analysis (automated differential) was performed to assess peripheral blood cell populations. $n \geq 10$ per group. A: Percentage of neutrophils. ${ }^{*} P<0.001$ versus $+/+\mathrm{VEH}$ ${ }^{\dagger} P<0.01$ versus $-/-$ VEH. B: Percentage of lymphocytes. ${ }^{*} P<0.001$ versus $+/+\mathrm{VEH} ;{ }^{\dagger} P<0.001$ versus $-/-$ VEH. C: Number of neutrophils. ${ }^{*} P<$ 0.01 versus $+/+\mathrm{VEH} ;{ }^{\dagger} P<0.05$ versus $-/-\mathrm{VEH}$. D: Number of lymphocytes. Data are expressed as means \pm SEM. 
A
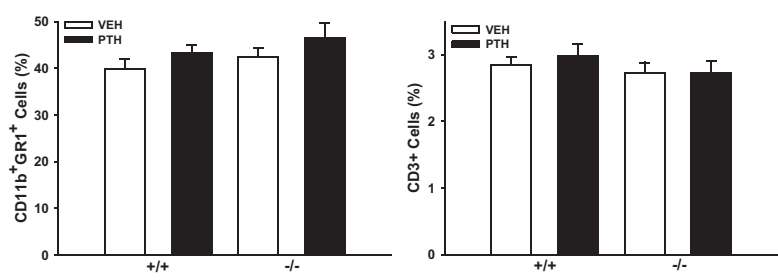

C

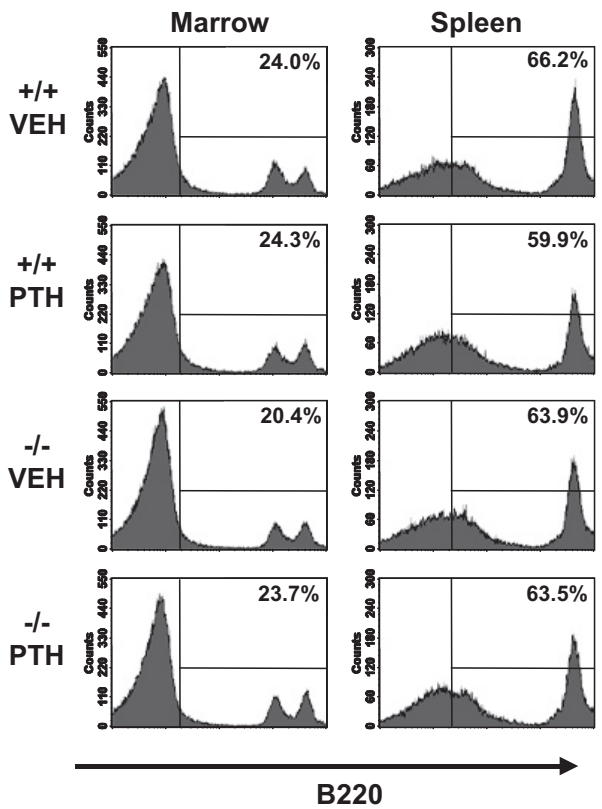

D

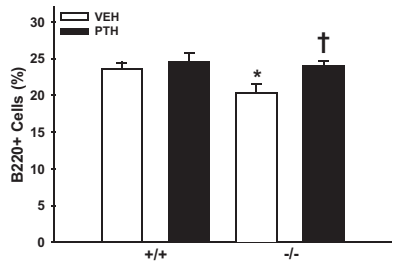

$\mathrm{E}$

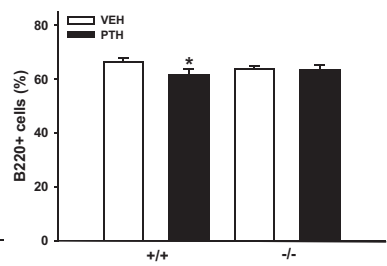

Figure 5. Bone marrow and spleen immune cell analyses. A-D: $\operatorname{Prg} 4^{-1-}$ mutant and $\operatorname{Prg} 4^{+/+}$wild-type mice were administered intermittent PTH(1-34) $(50 \mu \mathrm{g} / \mathrm{kg})$ or vehicle $(\mathrm{VEH})(0.9 \% \mathrm{NaCl})$ control subcutaneous injections daily for 6 weeks, from age 16 weeks to 22 weeks. The 22 week-old $\operatorname{Prg} 4^{-/-}$and $\operatorname{Prg} 4^{+/+}$mice were sacrificed and femur bone marrow cells were isolated for flow cytometric analysis of CD $11 b^{+} \mathrm{GR} 1^{+}$ (immature myeloid) cells ( $n \geq 9$ per group) $(\mathbf{A}), \mathrm{CD}^{+}$(T-lymphocytic) cells ( $n \geq 9$ per group) (B), and B220 (B-lymphocytic) cells ( $n \geq 9$ per group) (C and $\mathbf{D}$ ). $\mathbf{C}$ and $\mathbf{E}$ : Spleen cells were isolated for flow cytometric analysis of $\mathrm{B} 220^{+}$cells ( $n \geq 10$ per group). C: $\mathrm{B} 220^{+}$marrow and spleen cells. ${ }^{*} P<0.05$ versus $+/+\mathrm{VEH} ;{ }^{\dagger} P<0.05$ versus $-/-\mathrm{VEH}$. Data are expressed as means \pm SEM. Percentages shown are relative to total cells in marrow (A, B, and $\mathbf{D})$ or spleen $(\mathbf{E})$.

$\mathrm{CD}_{11 b^{+} \mathrm{GR}^{+}}{ }^{+}$(immature myeloid) cells, CD3 ${ }^{+}$(T-lymphocytic) cells, and $\mathrm{B}^{2} 2 \mathrm{O}^{+}$(B-lymphocytic) cells. The frequency of marrow $\mathrm{CD} 11 \mathrm{~b}^{+} \mathrm{GR} 1^{+}$cells and $\mathrm{CD} 3^{+}$cells did not differ between Prg $4^{-/-}$and $P r g 4^{+/+}$mice (Figure 5, A and B; see also Supplemental Figure S1 at http:// ajp.amjpathol.org). Similar to the peripheral blood lymphocyte findings, Prg4 ${ }^{-1-}$ mice had a reduced percentage of marrow $\mathrm{B}^{2} 2 \mathrm{O}^{+}$cells, which were normalized to levels of
$\mathrm{Prg}^{+/+}$mice with PTH treatment (Figure 5, C and D). Based on differences in peripheral blood lymphocytes and marrow B-lymphocytic cells, the frequency of B220 cells was assessed in the spleen, a center for B-lymphopoiesis. The frequency of $\mathrm{B}^{2} 20^{+}$cells in spleen was similar in 22-week-old Prg $4^{-1-}$ and $\mathrm{Prg}^{+/+}$mice (Figure $5, \mathrm{C}$ and $\mathrm{E})$. PTH decreased the percentage of splenic $\mathrm{B}_{2} 2 \mathrm{O}^{+}$cells in $\mathrm{Prg}^{+/+}$mice, an effect that may be secondary to PTH actions supporting the expansion of HPCs in the spleen. ${ }^{42}$ These data suggest that proteoglycan 4 restricts peripheral blood neutrophil numbers, which does not appear to be secondary to an altered frequency of marrow immature myeloid cells. Moreover, these data indicate that proteoglycan 4 supports the frequency of marrow B-lymphocytic cells.

\section{Prg4 ${ }^{-1-}$ Mice Have Decreased Expansion of Marrow HPCs Induced by PTH}

Recombinant HAPO administration increased marrow HPCs in normal mice and accelerated marrow hematopoietic reconstitution in mice subjected to irradiation ${ }^{14}$ or high-dose chemotherapy. ${ }^{15}$ To investigate the effect of proteoglycan 4 on marrow HPCs, we assessed the frequency of marrow Lin ${ }^{-} \mathrm{Sca}-1^{+} \mathrm{C}_{-} \mathrm{Kit}^{+}$(hematopoietic progenitor) cells in 22-week-old $\mathrm{Prg}^{-/-}$and $\mathrm{Prg}^{+/+}$mice by flow cytometric analysis (Figure 6). The percentage of marrow $\mathrm{Lin}^{-} \mathrm{Sca}-1^{+} \mathrm{C}-\mathrm{Kit}^{+}$cells was similar in vehicletreated $\mathrm{Prg}^{-1-}$ and $\mathrm{Prg} 4^{+/+}$mice. PTH increased the frequency of $\mathrm{Lin}^{-} \mathrm{Sca}-1^{+} \mathrm{C}-\mathrm{Kit}^{+}$cells in both $\mathrm{Prg}^{-1-}$ and $\mathrm{Prg}^{+/+}$marrow; however, this increase was blunted in $\mathrm{Prg}^{-1-}$ mice relative to Prg $4^{+/+}$littermates (Figure 6). These data suggest that proteoglycan 4 supports PTH actions increasing marrow HPCs.

\section{Marrow Megakaryopoiesis Is Similar in $\mathrm{Prg}^{-1-}$ and $\operatorname{Prg} 4^{+/+}$Mice}

Although there are no reported MSF studies in vivo, administration of purified MSF in vitro has been suggested to support the formation of platelet forming cells. ${ }^{17-19}$ To elucidate the effect of proteoglycan 4 on megakaryopoiesis, the frequency of marrow CD41+ (megakaryopoietic) cells and megakaryocyte ploidy (a relative measure of megakaryocyte maturity) were evaluated in 22-week-old $\mathrm{Prg}^{-1-}$ versus $\mathrm{Prg}^{+/+}$mice via flow cytometric analysis. The frequency of marrow CD $41^{+}$(megakaryopoietic) cells and megakaryocyte ploidy were similar in $\mathrm{Prg}^{-1-}$ and $\mathrm{Prg}^{+/+}$mice (see Supplemental Figure S2, A and B at http://ajp.amjpathol.org). Numbers of megakaryocytes per marrow area in proximal tibia sections were similar in 22-week-old Prg4 ${ }^{-1-}$ and Prg4 ${ }^{+/+}$mice (see Supplemental Figure S2, C and D, at http://ajp.amjpathol.org). These findings indicate that proteoglycan 4 is not a critical regulator of marrow megakaryopoiesis in vivo. 
A

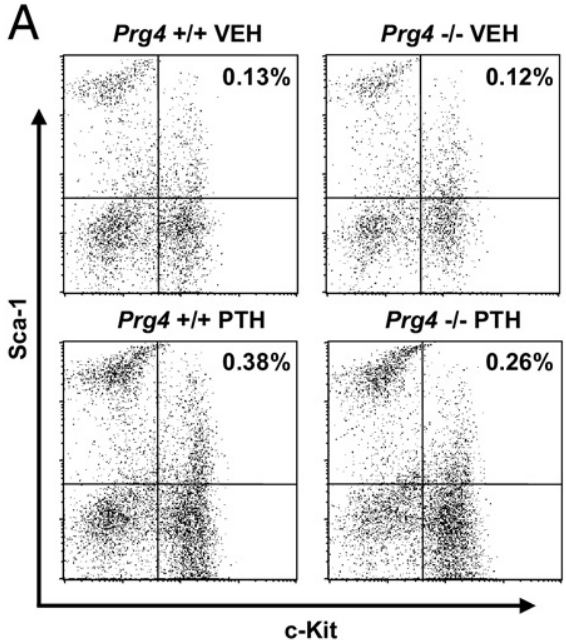

B

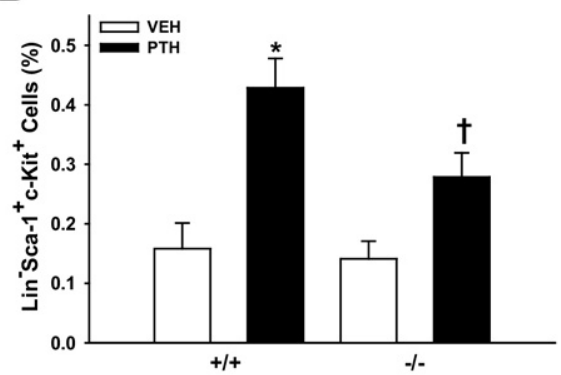

Figure 6. Bone marrow hematopoietic progenitor cell analyses. Prg $4^{-}$ mutant and $\operatorname{Prg} 4^{+/+}$wild-type mice were administered intermittent PTH(1$34)(50 \mu \mathrm{g} / \mathrm{kg})$ or vehicle (VEH) $(0.9 \% \mathrm{NaCl})$ control subcutaneous injections daily for 6 weeks, from age 16 weeks to 22 weeks. Femur bone marrow cells were isolated from 22-week-old $\operatorname{Prg} 4^{-1-}$ and $\operatorname{Prg} 4^{+/+}$mice for flow cytometric analysis of $\mathrm{Lin}^{-} \mathrm{Sca}-1^{+} \mathrm{C}-\mathrm{Kit}^{+}$(hematopoietic progenitor) cells ( $n \geq 6$ per group). A: Representative dot plots of FITC/c-Kit ( $x$ axis) versus PE/Sca- 1 ( $y$ axis) (gated for $\mathrm{Lin}^{-}$cell population). B: Percentage of $\mathrm{Lin}^{-} \mathrm{Sca}-1^{+} \mathrm{C}-\mathrm{Kit}^{+}$ cells, relative to total marrow cells. ${ }^{*} P<0.01$ versus $+/+\mathrm{VEH} ;{ }^{\dagger} P<0.05$ versus $-/-$ VEH $\&+/+$ PTH. Data are expressed as means \pm SEM.

\section{Prg4 ${ }^{-/-}$Mice Have Altered Marrow IL-6 mRNA and SDF-1 Protein}

Marrow IL-6 mRNA expression was measured in 22week-old PTH-treated and vehicle-treated $\mathrm{Prg}^{-1-}$ and $\mathrm{Prg}^{+/+}$mice (Figure 7A), because IL-6 mRNA levels in control 16-week-old Prg4 ${ }^{-1-}$ mice were decreased, relative to $\mathrm{Prg}^{+/+}$littermates. Similar to the 16-week-old Prg4 ${ }^{-/-}$mice, control 22-week-old Prg $4^{-1-}$ mice had decreased marrow IL-6 mRNA levels, compared with Prg4 ${ }^{+/+}$littermates (Figure 7A). These data suggest that Prg4 signaling supports basal IL-6 mRNA expression in the bone marrow.

Based on the findings that 22-week-old Prg $4^{-1-}$ mice have increased numbers of peripheral neutrophils, decreased frequency of marrow B-lymphocytes, and a blunted PTH-induced increase in marrow HPC frequency, we assessed marrow SDF-1 mRNA and protein expression in 22-week-old Prg $4^{-1-}$ versus Prg $4^{+/+}$mice. Quantitative real-time PCR analysis demonstrated similar marrow SDF-1 mRNA levels in Prg $4^{-1-}$ and $P r g 4^{+/+}$mice (Figure 7B), which indicates that Prg4 does not affect
A

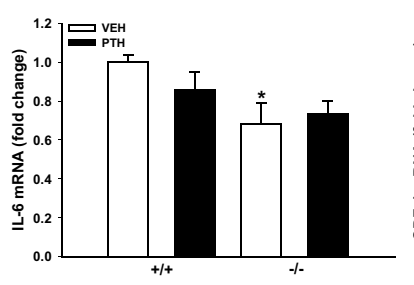

B
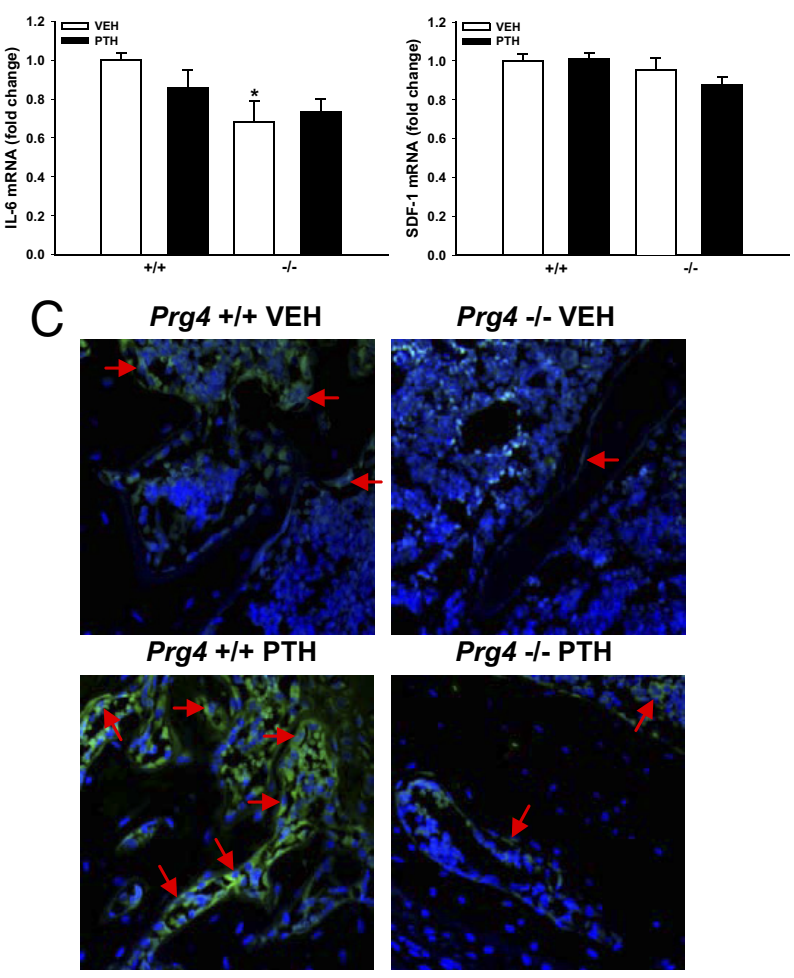

Prg 4 -/- VEH

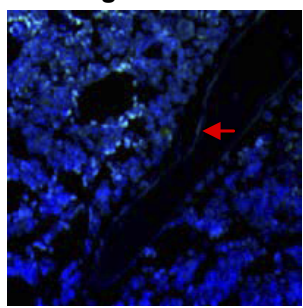

Prg4 -/- PTH

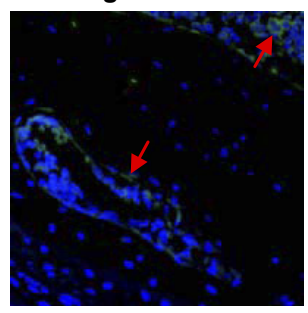

$\mathrm{E}$
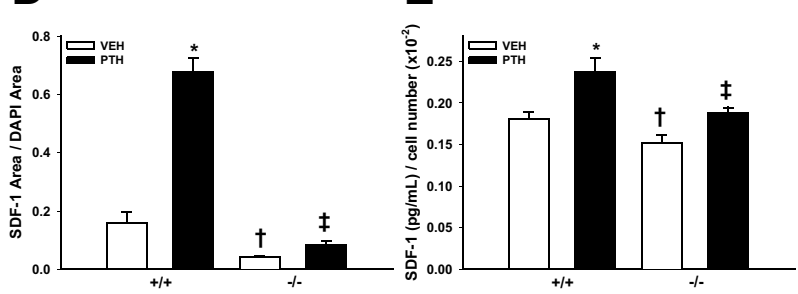

Figure 7. Bone marrow IL-6 and SDF-1 expression. A-E: $\operatorname{Prg} 4^{-/-}$mutant and $\operatorname{Prg} 4^{+/+}$wild-type mice were administered intermittent PTH(1-34) (50 $\mu \mathrm{g} / \mathrm{kg})$ or vehicle $(\mathrm{VEH})(0.9 \% \mathrm{NaCl})$ control subcutaneous injections daily for 6 weeks, from age 16 weeks to 22 weeks. A and B: Bone marrow was harvested from 22-week-old $\operatorname{Prg} 4^{-/-}$and $\operatorname{Prg} 4^{+/+}$mice $(n=5$ per group) for quantitative real-time PCR analysis of IL-6 (A) and SDF-1 (B) mRNA expression, standardized to GAPDH levels. Relative quantification of data was performed using the comparative $C_{t}$ method. A: Marrow IL- 6 mRNA expression. ${ }^{*} P<0.05$ versus +/+ VEH. B: Marrow SDF-1 mRNA expression. $\mathbf{C}$ and $\mathbf{D}$ : SDF-1 immunofluorescence analysis was performed on proximal tibia (secondary spongiosa) sections of 22 -week-old mice ( $n=6$ per group). C: Representative SDF-1 immunofluorescence-labeled proximal tibia sections (green, SDF-1; blue, DAPI); arrows indicate selected SDF- $1^{+}$stromal osteoblastic cells. Original magnification, $\times 60$. D: SDF- 1 area/DAPI area. ${ }^{*} P<$ 0.001 versus $+/+\mathrm{VEH} ;{ }^{\dagger} P<0.01$ versus $+/+\mathrm{VEH} ;{ }^{\ddagger} P<0.05$ versus $-/-$ VEH \& +/ + PTH. E: ELISA analysis of bone marrow SDF-1 levels in $22-$ week-old Prg 4 mice, showing marrow SDF-1 (pg/mL) normalized to marrow cell numbers ( $n \geq 5$ per group). ${ }^{*} P<0.05$, versus $+/+\mathrm{VEH} ;{ }^{\dagger} P<0.05$, versus $+/+\mathrm{VEH} ;{ }^{\ddagger} P<0.05$, versus $-/-\mathrm{VEH} \&+/+$ PTH. Data are expressed as means \pm SEM.

basal SDF-1 mRNA expression in the marrow. SDF-1 immunofluorescence analysis in proximal tibia (Figure 7 , $\mathrm{C}$ and D) and SDF-1 ELISA analysis of hindlimb marrow (Figure 7E) demonstrated that SDF-1 protein was reduced in the marrow of Prg $4^{-1-}$ mice, compared with $\mathrm{Prg}^{+/+}$mice. PTH significantly increased SDF-1 protein expression in the marrow of $\mathrm{Prg}^{-1-}$ and $\mathrm{Prg}^{+/+}$mice; however, this was blunted in $\operatorname{Prg}^{-1-}$ mice relative to 
Prg $4^{+/+}$littermates (Figure 7, C-E). These data indicate that proteoglycan 4 supports basal marrow SDF-1 protein expression and the ability of PTH to increase SDF-1 protein expression in the bone marrow.

\section{Discussion}

Prg4 expression in the bone marrow of the mature skeleton suggests that proteoglycan 4 may affect adult hematopoiesis. That basal Prg4 mRNA expression was higher in less differentiated osteoblastic cell cultures suggests that more immature osteoblastic cells are a primary source of proteoglycan 4 in the bone marrow. Considering that more immature osteoblastic cells have been implicated in HPC expansion and function, ${ }^{43}$ the finding that basal Prg4 mRNA expression is higher in less differentiated osteoblastic cell cultures suggests that proteoglycan 4 may be involved in the mechanism by which more immature osteoblastic cells support HPCs.

The in vivo PTH-induced increase in bone marrow Prg4 mRNA indicates that proteoglycan 4 could be a mediator of PTH biological actions in marrow hematopoiesis. Based on the PTH-induced increase in Prg4 mRNA in isolated osteoblastic cell cultures, we speculate that direct PTH signaling at PPR-expressing osteoblastic cells increases proteoglycan 4 secretion in the marrow, mediating paracrine signaling to hematopoietic cells. The finding that PTH increased Prg4 mRNA to consistently high levels in differentiated osteoblastic cell cultures, despite the lower basal levels, may simply reflect the greater PPR activity in more differentiated osteoblastic cells. ${ }^{27}$

The dysregulated immune cell populations noted in Prg4 mutant mice may be secondary to the decreased basal expression of marrow SDF-1 protein and marrow IL-6 mRNA. Marrow and peripheral neutrophils express the SDF-1 receptor CXCR4 and have been shown to biologically respond to SDF-1..$^{39,44-46}$ Studies have demonstrated that the CXCR4/SDF-1 chemokine axis regulates circulating neutrophil homeostasis. ${ }^{39,40,47}$ Injection of CXCR4-blocking antibody in mice mobilized neutrophils from the marrow, ${ }^{39}$ and drugs targeting CXCR4 induced a peripheral neutrophilia in mice and humans. ${ }^{47}$ Because the Prg4 mutant mouse does not display signs of acute inflammation, which would induce the mobilization of immature neutrophils from the marrow into circulation, we speculate that decreased marrow SDF-1 disrupts the neutrophil CXCR4/SDF-1 axis, resulting in increased circulating neutrophils in the Prg4 mutant mouse.

The decreased frequency of peripheral blood lymphocytes in Prg4 mutant mice appears to be secondary to increased absolute numbers of peripheral blood neutrophils. Nevertheless, the frequency of marrow B-lymphocytic cells was significantly decreased in Prg4 mutant mice. Although the slight decrease in Prg4 mutant marrow $\mathrm{B}_{220^{+}}$cells implies that proteoglycan 4 is not a critical regulator of marrow B-lymphocyte cell numbers under normal physiological conditions, proteoglycan 4 actions supporting $\mathrm{B}_{22 \mathrm{O}^{+}}$cell numbers may play a more crucial role during immune response.
The decreased expression of marrow SDF- 1 protein in Prg4 mutant mice may contribute to the reduced frequency of marrow B-lymphocytic cells. B-lymphocyte progenitor cells express the CXCR4 receptor at high levels. ${ }^{48,49}$ Mice deficient in SDF-1 have severely reduced B-lymphocyte progenitors in the marrow, ${ }^{50,51}$ and studies have demonstrated that SDF-1 supports the homing $^{40,48,49}$ and proliferation ${ }^{52}$ of marrow B-lymphocyte progenitors. Furthermore, reduced marrow IL-6 mRNA expression in Prg4 mutant mice may contribute to decreased frequency of B-lymphocytic cells, because IL-6 supports physiological B-lymphopoiesis. ${ }^{28,53,54}$ Similar to Prg4 mutant mice, mice with an osteoprogenitor cell $\mathrm{G}_{\mathrm{s}} \alpha$ deficiency (a downstream mediator of the PPR) have decreased peripheral blood and marrow B-lymphocytic cells, ${ }^{55}$ suggesting that osteoblast cell signaling also could play a role in Prg4 mutant mice. The unexpected finding that PTH induced normalization of peripheral blood neutrophils and marrow B-lymphocytic cells in Prg4 mutant mice to wild-type levels may be associated with the PTH-induced increase in marrow SDF-1 protein in Prg4 mutant mice.

The similar frequency of marrow $\mathrm{Lin}^{-} \mathrm{Sca}-1^{+} \mathrm{C}-\mathrm{Kit}^{+}$ cells in Prg4 mutant and wild-type mice suggests that proteoglycan 4 is not a critical regulator of physiological marrow HPC numbers. The finding that PTH increased $\mathrm{Lin}^{-} \mathrm{Sca}-1^{+} \mathrm{C}-\mathrm{Kit}^{+}$cells significantly more in Prg4 wildtype mice indicates that proteoglycan 4 supports PTH actions on HPC expansion. We speculate that, although basal proteoglycan 4 expression does not affect HPC numbers, the PTH-induced increase in proteoglycan 4 supports HPC expansion, a concept that is supported by HAPO studies. ${ }^{14,15}$ Daily intermittent subcutaneous injection of recombinant HAPO in normal mice increases marrow HPC populations, including $\mathrm{CD}_{3}{ }^{+}, \mathrm{C}^{-} \mathrm{Kit}^{+}$, and Sca- $1^{+}$cells. ${ }^{14}$ Because SDF- 1 is a potent chemoattractant that regulates the homing and mobilization of marrow HPC cells, ${ }^{36,37,56,57}$ the blunted ability of PTH to increase SDF-1 in the marrow of Prg4 mutant mice may be linked to the blunted PTH expansion of marrow HPCs in Prg4 mutant mice.

PTH increased bone marrow and calvarial IL-6 mRNA to a greater extent in Prg4 mutant mice; thus, in the absence of Prg4, PTH differentially regulates the expression of PTH response-associated genes, which may represent an attempt at compensation for the absence of proteoglycan 4. IL-6 supports HPC proliferation, ${ }^{28,29,58,59}$ and we have recently shown it to be a critical regulator of PTH actions in HPC expansion. ${ }^{13}$

Because the calvarial organ is composed primarily of stromal osteoblastic cells, the predominant PPR-expressing cell population in the bone marrow, the more significantly increased PTH-induced IL-6 mRNA in Prg4 mutant calvaria suggests that a stromal osteoblastic cell is the target of PTH actions to modulate IL-6 and hematopoietic cells in the marrow of Prg4 mutant mice. Because PTH modulated other responsiveness genes similarly in both Prg4 mutant and wild-type mice, the heightened IL-6 regulation in Prg4 mutant mice points to the likelihood of a specific compensatory effect occurring with the loss of proteoglycan 4 activity. 
Although it has been reported that the Prg4 protein product MSF stimulates the growth of platelet forming cells in vitro, ${ }^{17-19}$ the similar number of peripheral blood platelets, similar frequency of marrow $\mathrm{CD} 41^{+}$cells, similar marrow megakaryocyte ploidy, and similar number of megakaryocytes per marrow area in Prg4 mutant and wild-type mice all suggest that proteoglycan 4 is not a critical regulator of physiological megakaryopoiesis in vivo.

PRG4 actions on SDF-1 are unknown. The decreased SDF-1 protein levels in the marrow of Prg 4 mutant mice imply that proteoglycan 4 may interact with and increase the concentration of SDF-1 in the marrow. This is supported by prior studies, which have demonstrated that SDF-1 binds cellular proteoglycans in the bone marrow. ${ }^{60-64}$ A single PTH injection significantly increased SDF-1 mRNA in the marrow of wild-type but not mutant mice, which may explain the blunted increase in marrow SDF-1 protein levels in PTH-treated Prg4 mutant mice. In the light of recent work demonstrating that intermittent PTH administration inhibits dipeptidyl peptidase-IV (DPPIV), ${ }^{65}$ an enzyme that functionally degrades SDF-1, an alternative explanation for the blunted PTH increase in marrow SDF-1 is that PTH actions protecting marrow SDF-1 from enzymatic degradation are decreased in Prg4 mutant mice.

The present investigation of Prg4 actions on hematopoiesis revealed that proteoglycan 4 regulates marrow SDF-1 levels, immune cell populations, and PTH actions increasing marrow SDF-1 and HPCs. SDF-1 is a candidate regulator of proteoglycan 4 actions on hematopoiesis. Contrary to findings from other studies in which proteoglycan 4 was administered, characterization of the Prg4 mutant mouse model demonstrates that basal proteoglycan 4 expression does not affect megakaryopoiesis or HPC frequency. Although CACP patients have not been reported to spontaneously develop peripheral hematological abnormalities, we are unaware of any studies that characterize their bone marrow cell populations. The present study reveals that loss-of-function mutations in Prg4 may result in altered immune cell populations, some of which are compensated for but which could also have implications for immune response. In summary, proteoglycan 4 is a novel immunomodulatory factor regulating physiological immune cell populations and PTH actions on hematopoiesis.

\section{Acknowledgments}

We thank Dr. Matthew Warman for providing the Prg4 mutant mice, Dr. Hedwig Murphy for scientific discussions, and Chris Strayhorn and Payam Entezami for assistance with histological procedures.

\section{References}

1. Kousteni S, Bilezikian JP: Cellular actions of parathyroid hormone. Principles of Bone Biology, ed 3. Edited by JP Bilezikian, LG Raisz, TJ Martin. 2008, pp 639-656

2. Calvi LM, Adams GB, Welbrecht KW, Weber JM, Olson DP, Knight MC, Martin RP, Schipani E, Divieti P, Bringhurst FR, Milner LA, Kronenberg HM, Scadden DT: Osteoblastic cells regulate the haematopoietic stem cell niche. Nature 2003, 425:841-846
3. Brunner S, Zaruba M, Huber B, David R, Vallaster M, Assmann G, Mueller-Hoecker J, Franz WM: Parathyroid hormone effectively induces mobilization of progenitor cells without depletion of bone marrow. Exp Hematol 2008, 36:1157-1166

4. Adams GB, Martin RP, Alley IR, Chabner KT, Cohen KS, Calvi LM, Kronenberg HM, Scadden DT: Therapeutic targeting of a stem cell niche [Erratum appeared in Nat Biotechnol 2007, 25:944, and in Nat Biotechnol 2008, 26:241]. Nat Biotechnol 2007, 25:238-243

5. Ballen KK, Shpall EJ, Avigan D, Yeap BY, Fisher DC, McDermott K, Dey BR, Attar E, McAfee S, Konopleva M, Antin JH, Spitzer TR: Phase I trial of parathyroid hormone to facilitate stem cell mobilization. Biol Blood Marrow Transplant 2007, 13:838-843

6. McCauley LK, Rosol TJ, Merryman JI, Capen CC: Parathyroid hormone-related protein binding to human T-cell lymphotropic virus type-I-infected lymphocytes. Endocrinology 1992, 130:300-306

7. Terauchi M, Li JY, Bedi B, Baek KH, Tawfeek H, Galley S, Gilbert L, Nanes MS, Zayzafoon M, Guldberg R, Lamar DL, Singer MA, Lane TF, Kronenberg HM, Pacifici R: T lymphocytes amplify the anabolic activity of parathyroid hormone through Wnt10b signaling. Cell Metab 2009, 10:229-240

8. Li X, Liu H, Qin L, Tamasi J, Bergenstock M, Shapses S, Feyen JH, Notterman DA, Partridge NC: Determination of dual effects of parathyroid hormone on skeletal gene expression in vivo by microarray and network analysis. J Biol Chem 2007, 282:33086-33097

9. Ma YL, Cain RL, Halladay DL, Yang X, Zeng Q, Miles RR, Chandrasekhar S, Martin TJ, Onyia JE: Catabolic effects of continuous human PTH (1-38) in vivo is associated with sustained stimulation of RANKL and inhibition of osteoprotegerin and gene-associated bone formation. Endocrinology 2001, 142:4047-4054

10. Locklin RM, Khosla S, Turner RT, Riggs BL: Mediators of biphasic responses of bone to intermittent and continuously administered parathyroid hormone. J Cell Biochem 2003, 89:180-190

11. Silvestrini G, Ballanti $P$, Leopizzi M, Gualtieri N, Sardella D, Monnazzi P, Simeoni S, Sebastiani M, Bonucci E, Patacchioli FR: Effects of the administration of corticosterone, parathyroid hormone, or both, and of their withdrawal, on rat bone and cartilage histomorphometric parameters, and on osteoprotegerin and RANKL mRNA expression and proteins. J Mol Histol 2007, 38:215-226

12. Lee SK, Lorenzo JA: Parathyroid hormone stimulates TRANCE and inhibits osteoprotegerin messenger ribonucleic acid expression in murine bone marrow cultures: correlation with osteoclast-like cell formation. J Bone Miner Res 1999, 140:3552-3561

13. Pirih FQ, Michalski MN, Cho SW, Koh AJ, Berry JE, Ghaname E, Kamarajan P, Bonnelye E, Ross CW, Kapila YL, Jurdic P, McCauley LK: Parathyroid hormone mediates hematopoietic cell expansion through interleukin-6. PLoS One 2010, 5:e13657

14. Liu YJ, Lu SH, Xu B, Yang RC, Ren Q, Liu B, Li B, Lu M, Yan FY, Han ZB, Han ZC: Hemangiopoietin, a novel human growth factor for the primitive cells of both hematopoietic and endothelial cell lineages. Blood 2004, 103:4449-4456

15. Xu ZL, Zhou B, Cong XL, Liu YJ, Xu B, Li YH, Gu J, Han ZC: Hemangiopoietin supports animal survival and accelerates hematopoietic recovery of chemotherapy-suppressed mice. Eur J Haematol 2007, 79:477-485

16. Xu ZS, Liu YJ, Lv LL, Han ZB, He R, Lu SH, Wang T, Xu B, Chen ZZ, Han ZC: Bone marrow stromal cells transduced with human hemangiopoietin gene support hematopoiesis in vitro. Haematologica 2005, 90:157-165

17. Merberg DM, Fitz LJ, Temple P, Giannotti J, Murtha P, Fitzgerald M, Scaltreto H, Kelleher K, Preissner K, Kriz R, Jacobs K, Turner K: A comparison of vitronectin and megakaryocyte stimulating factor. Biology of Vitronectins and Their Receptors: Proceedings of the First International Vitronectin Workshop, Rauischholzhausen Castle, Marburg, Germany, 25-28 August, 1993. Edited by KT Preissner, S Rosenblatt, C Kost, J Wegerhoff, DF Mosher. Philadelphia, Elsevier, 1992, pp 45-53

18. Greenberg SM, Kuter DJ, Rosenberg RD: In vitro stimulation of megakaryocyte maturation by megakaryocyte stimulatory factor. J Biol Chem 1987, 262:3269-3277

19. Tayrien G, Rosenberg RD: Purification and properties of a megakaryocyte stimulatory factor present both in the serum-free conditioned medium of human embryonic kidney cells and in thrombocytopenic plasma. J Biol Chem 1987, 262:3262-3268 
20. Novince CM, Koh AJ, Marchesan JT, McCauley LK: Proteoglycan-4: a novel gene regulating parathyroid hormone actions in bone anabolism and hematopoiesis (abstract 1186). ASBMR 31st Annual Meeting 1001-1300. J Bone Miner Res 2009, 24:S56-S57

21. Novince CM, Michalski MN, Sinder BP, Entezami P, Koh AJ, Eber MJ, Pettway GJ, Rosol TJ, Wronski TJ, Kozloff KM, McCauley LK. Proteoglycan 4: a dynamic regulator of skeletogenesis and PTH skeletal anabolism. J Bone Miner Res 2011, doi: 10.1002/jbmr.508

22. Ikegawa S, Sano M, Koshizuka Y, Nakamura Y: Isolation, characterization and mapping of the mouse and human PRG4 (proteoglycan 4) genes. Cytogenet Genome Res 2000, 90:291-297

23. Rhee DK, Marcelino J, Baker M, Gong Y, Smits P, Lefebvre V, Jay GD, Stewart M, Wang H, Warman ML, Carpten JD: The secreted glycoprotein lubricin protects cartilage surfaces and inhibits synovial cell overgrowth. J Clin Invest 2005, 115:622-631

24. Schumacher BL, Block JA, Schmid TM, Aydelotte MB, Kuettner KE: A novel proteoglycan synthesized and secreted by chondrocytes of the superficial zone of articular cartilage. Arch Biochem Biophys 1994 311:144-152

25. Marcelino J, Carpten JD, Suwairi WM, Gutierrez OM, Schwartz S, Robbins C, Sood R, Makalowska I, Baxevanis A, Johnstone B, Laxer RM, Zemel L, Kim CA, Herd JK, Ihle J, Williams C, Johnson M, Raman V. Alonso LG, Brunoni D, Gerstein A, Papadopoulos N, Bahabri SA, Trent JM, Warman ML: CACP, encoding a secreted proteoglycan, is mutated in camptodactyly-arthropathy-coxa vara-pericarditis syndrome. Nat Genet 1999, 23:319-322

26. Schmittgen TD, Livak KJ: Analyzing real-time PCR data by the comparative CT method. Nat Protocols 2008, 3:1101-1108

27. McCauley LK, Koh AJ, Beecher CA, Cui Y, Decker JD, Francheschi RT: Effects of differentiation and transforming growth factor beta on PTH/PTHrP receptor mRNA levels in МС3T3-E1 cells. J Bone Miner Res 1995, 10:1243-1255

28. Kopf M, Ramsay A, Brombacher F, Baumann H, Freer G, Galanos C, Gutierrez-Ramos JC, Köhler G: Pleiotropic defects of IL-6-deficient mice including early hematopoiesis. $T$ and $B$ cell function, and acute phase responses. Ann N Y Acad Sci 1985, 21:308-318

29. Ikebuchi K, Wong GG, Clark SC, Inle JN, Hirai Y, Ogawa M: Interleukin 6 enhancement of interleukin 3-dependent proliferation of multipotential hemopoietic progenitors. Proc Natl Acad Sci USA 1987, 84:9035-9039

30. Imai T, Koike K, Kubo T, Kikuchi T, Amano Y, Takagi M, Okumura N, Nakahata T: Interleukin-6 supports human megakaryocytic proliferation and differentiation in vitro. Blood 1991, 78:1969-1974

31. Hill RJ, Warren MK, Stenberg P, Levin J, Corash L, Drummond R, Baker G, Levin F, Mok Y: Stimulation of megakaryocytopoiesis in mice by human recombinant interleukin-6. Blood 1991, 77:42-48

32. Greenfield EM, Gornik SA, Horowitz MC, Donahue HJ, Shaw SM: Regulation of cytokine expression in osteoblasts by parathyroid hormone: rapid stimulation of interleukin-6 and leukemia inhibitory factor mRNA. J Bone Miner Res 1993, 8:1163-1171

33. Onyia JE, Bidwell J, Herring J, Hulman J, Hock JM: In vivo, human parathyroid hormone fragment (hPTH 1-34) transiently stimulates immediate early response gene expression, but not proliferation, in trabecular bone cells of young rats. Bone 1995, 17:479-484

34. Pollock JH, Blaha MJ, Lavish SA, Stevenson S, Greenfield EM: In vivo demonstration that parathyroid hormone and parathyroid hormonerelated protein stimulate expression by osteoblasts of interleukin-6 and leukemia inhibitory factor. J Bone Miner Res 1996, 11:754-759

35. Murone M, Carpenter DA, de Sauvage FJ: Hematopoietic deficiencies in c-mpl and TPO knockout mice. Stem Cells 1998, 16:1-6

36. Peled A, Petit I, Kollet O, Magid M, Ponomaryov T, Byk T, Nagler A, Ben-Hur H, Many A, Shultz L, Lider O, Alon R, Zipori D, Lapidot T: Dependence of human stem cell engraftment and repopulation of NOD/SCID mice on CXCR4. Science 1999, 283:845-848

37. Jo DY, Rafii S, Hamada T, Moore MA: Chemotaxis of primitive hematopoietic cells in response to stromal cell-derived factor-1. J Clin Invest 2000, 105:101-111

38. Wang JF, Liu ZY, Groopman JE: The alpha-chemokine receptor CXCR4 is expressed on the megakaryocytic lineage from progenitor to platelets and modulates migration and adhesion. Blood 1998, 92:756-764

39. Suratt BT, Petty JM, Young SK, Malcom KC, Lieber JA, Nick JA Gonzalo JA, Henson PM, Worthen GS: Role of the CXCR4/SDF-1 chemokine axis in circulating neutrophil homeostasis. Blood 2004 104:565-571

40. Ma $Q$, Jones $D$, Springer TA: The chemokine receptor CXCR4 is required for the retention of $\mathrm{B}$ lineage and granulocytic precursors within the bone marrow microenvironment. Immunity 1999, 10:463471

41. Jung $Y$, Wang J, Schneider A, Sun YX, Koh-Paige AJ, Osman NI, McCauley LK, Taichman RS: Regulation of SDF-1 (CXCL12) production by osteoblasts in the hematopoietic microenvironment and a possible mechanism for stem cell homing. Bone 2006, 38:497-508

42. Jacome-Galarza CE, Lee SK, Lorenzo JA, Aguila HL: Parathyroid hormone regulates the distribution and osteoclastogenic potential of hematopoietic progenitors in the bone marrow. J Bone Miner Res 2011, 26:1207-1216

43. Cheng YH, Chitteti BR, Streicher DA, Morgan JA, Rodriguez-Rodriguez S, Carlesso N, Srour EF, Kacena MA: Impact of maturational status on the ability of osteoblasts to enhance the hematopoietic function of stem and progenitor cells. J Bone Miner Res 2011, 26: $1111-1121$

44. Gonzalo JA, Lloyd CM, Peled A, Delaney T, Coyle AJ, GutierrezRamos JC: Critical involvement of the chemotactic axis CXCR4/stromal cell-derived factor-1 alpha in the inflammatory component of allergic airway disease. J Immunol 2000, 165:499-508

45. Gupta SK, Pillarisetti K, Aiyar N: CXCR4 undergoes complex lineage and inducing agent-dependent dissociation of expression and functional responsiveness to SDF-1alpha during myeloid differentiation. J Leukocyte Biol 2001, 70:431-438

46. Förster R, Kremmer E, Schubel A, Breitfeld D, Kleinschmidt A, Nerl C, Bernhardt G, Lipp M: Intracellular and surface expression of the HIV-1 coreceptor CXCR4/fusin on various leukocyte subsets: rapid internalization and recycling upon activation. J Immunology 1998, 160:1522-1531

47. Hendrix CW, Flexner C, MacFarland RT, Giandomenico C, Fuchs EJ, Redpath E, Bridger G, Henson GW: Pharmacokinetics and safety of AMD-3100, a novel antagonist of the CXCR-4 chemokine receptor, in human volunteers. Antimicrob Agents Chemother 2000, 44:16671673

48. D'Appuzzo M, Rolink A, Loetscher M, Hoxie JA, Clark-Lewis I, Melchers F, Baggiolini M, Moser M: The chemokine SDF-1, stromal cell-derived factor 1 , attracts early stage B cell precursors via the chemokine receptor CXCR4. Eur J Immunol 1997, 27:1788-1793

49. Fedyk ER, Ryyan DH, Ritterman I, Springer TA: Maturation decreases responsiveness of human bone marrow $B$ lineage cells to stromalderived factor 1 (SDF-1). J Leukocyte Biol 1999, 66:667-673

50. Nagasawa T, Hirota S, Tachibana K, Takakura N, Nishikawa S, Kitamura Y, Yoshida N, Kikutani H, Kishimoto T: Defects of B-cell lymphopoiesis and bone-marrow myelopoiesis in mice lacking the CXC chemokine PBSF/SDF-1. Nature 1996, 382:635-638

51. Ma Q, Jones D, Borghesani PR, Segal RA, Nagasawa $T$, Kishimoto $T$, Bronson RT, Springer TA: Impaired B-lymphopoiesis, myelopoiesis, and derailed cerebellar neuron migration in CXCR4- and SDF-1deficient mice. Proc Natl Acad Sci USA 1998, 95:9448-9453

52. Nagasawa $T$, Kikutani $H$, Kishimoto $T$ : Molecular cloning and structure of a pre-B-cell growth-stimulating factor. Proc Natl Acad Sci USA 1994, 91:2305-2309

53. Kopf M, Baumann H, Freer G, Freudenberg M, Lamers M, Kishimoto $\mathrm{T}$, Zinkernagel R, Bluethmann H, Köhler G: Impaired immune and acute-phase responses in interleukin-6-deficient mice. Nature 1994, 368:339-342

54. Zhu J, Garrett R, Jung Y, Zhang Y, Kim N, Wang J, Joe GJ, Hexner E, Choi Y, Taichman RS, Emerson SG: Osteoblasts support B-lymphocyte commitment and differentiation from hematopoietic stem cells [Erratum appeared in Blood 2007 Jul 1;110(1):17]. Blood 2007, 109: 3706-3712

55. Wu JY, Purton LE, Rodda SJ, Chen M, Weinstein LS, McMahon AP, Scadden DT, Kronenberg HM: Osteoblastic regulation of B lymphopoiesis is mediated by Gs\{alpha\}-dependent signaling pathways. Proc Natl Acad Sci USA 2008, 105:16976-16981

56. Aiuti A, Webb IJ, Bleul C, Springer T, Gutierrez-Ramos JC: The chemokine SDF-1 is a chemoattractant for human CD34+ hematopoietic progenitor cells and provides a new mechanism to explain the mobilization of CD34+ progenitors to peripheral blood. J Exp Med 1997, 185:111-120 
57. Mohle R, Bautz F, Rafii S, Moore J, Brugger W, Kanz L: The chemokine receptor CXCR-4 is expressed on CD34+ hematopoietic progenitors and leukemic cells and mediates transendothelial migration induced by stromal cell-derived factor-1. Blood 1998, 91:4523-4530

58. Rodríguez MC, Bernad A, Aracil M: Interleukin-6 deficiency affects bone marrow stromal precursors, resulting in defective hematopoietic support. Blood 2004, 103:3349-3354

59. Bernad A, Kopf M, Kulbacki R, Weich N, Koehler G, Gutierrez-Ramos JC: Interleukin-6 is required in vivo for the regulation of stem cells and committed progenitors of the hematopoietic system. Immunity 1994, 1:725-731

60. Amara A, Lorthioir O, Valenzuela A, Magerus A, Thelen M, Montes M, Virelizier JL, Delepierre M, Baleux F, Lortat-Jacob H, Arenzana-Seisdedos F: Stromal cell-derived factor-1alpha associates with heparan sulfates through the first beta-strand of the chemokine. J Biol Chem 1999, 274:23916-23925

61. Mbemba E, Gluckman JC, Gattegno L: Glycan and glycosaminoglycan binding properties of stromal cell-derived factor (SDF)-1alpha. Glycobiology 2000, 10:21-29
62. Netelenbos T, Zuijderduin S, Van Den Born J, Kessler FL, Zweegman S, Huijgens PC, Dräger AM: Proteoglycans guide SDF-1-induced migration of hematopoietic progenitor cells. J Leukocyte Biol 2002, 72:353-362

63. Netelenbos T, van den Born J, Kessler FL, Zweegman S, Merle PA, van Oostveen JW, Zwaginga JJ, Huijgens PC, Dräger AM: Proteoglycans on bone marrow endothelial cells bind and present SDF-1 towards hematopoietic progenitor cells. Leukemia 2003, 17:175-184

64. Santiago B, Baleux F, Paleo P, Gutiérrez-Cañas I, Ramírez JC Arenzana-Seisdedos F, Pablos JL: CXCL12 is displayed by rheumatoid endothelial cells through its basic amino-terminal motif on heparan sulfate proteoglycans. Arthritis Res Ther 2006, 8:R43

65. Huber BC, Brunner S, Segeth A, Nathan P, Fischer R, Zaruba MM, Vallaster M, Theiss HD, David R, Gerbitz A, Franz WM: Parathyroid hormone is a DPP-IV inhibitor and increases SDF-1-driven homing of $\mathrm{CXCR}^{+}{ }^{+}$stem cells into the ischaemic heart. Cardiovasc Res 2011 , 90:529-537 